
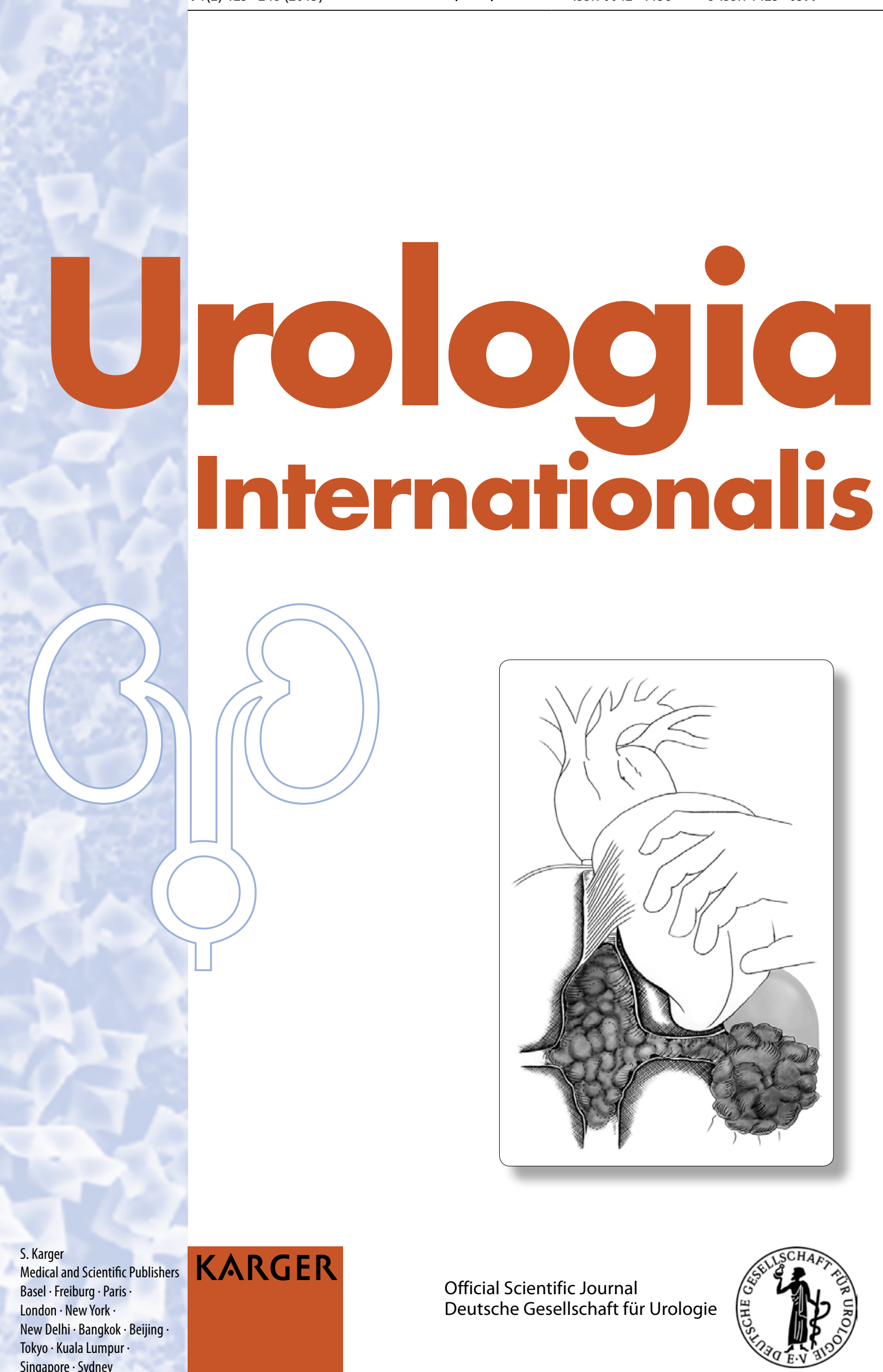


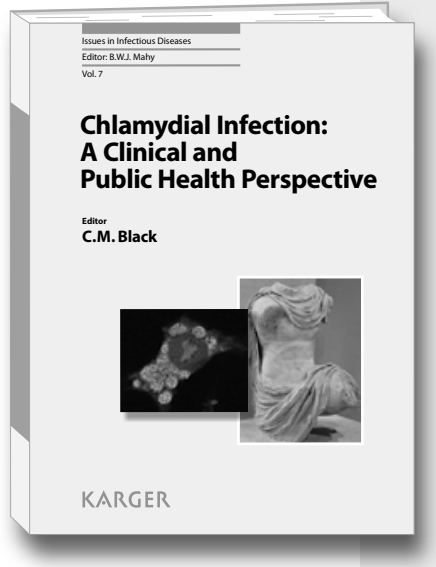

Chlamydial Infection: A Clinical and Public Health Perspective

Editor: Black, C.M. (Atlanta, Ga)

$\mathrm{VI}+162$ p., 12 fig. 3 in color, 12 tab., 2013

CHF 117.- / EUR 98.- / USD 138.00 (hard cover)

CHF 140.- / EUR 118.- / USD 166.00 (online)

Online version for institutional purchase

Prices subject to change

EUR price for Germany, USD price for USA only

ISBN 978-3-318-02398-5 (hard cover)

e-ISBN 978-3-318-02399-2

Issues in Infectious Diseases, Vol. 7

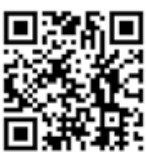

Dear Librarian

I have reviewed this publication and would like to recommend it for our library. Recommended by:

\section{Department:}

Date:

Orders may be placed with any bookshop, subscription agency, directly with the publisher or through a Karger distributor.

\title{
Chlamydial Infection: A Clinical and Public Health Perspective
}

\author{
Editor \\ Carolyn M. Black
}

Chlamydiae are obligate intracellular bacteria that cause one of the most common sexually transmitted infectious diseases in the world. The infection disproportionately impacts women and the highest prevalence of infection is found in adolescents. Most chlamydial infections are asymptomatic. Untreated infections are sources of further spread of infection and can lead to serious consequences including pelvic inflammatory disease, infertility and chronic pelvic pain. Chlamydial infections also increase a person's susceptibility to HIV and other STDs.

Featuring contributions by internationally recognized experts in epidemiology, infectious disease research and chlamydial biology, this book provides up-to-date reviews from a clinical and public health perspective on chlamydia epidemiology and control programs, genomics and pathogenicity, diagnosis, treatment, host immune responses, and the latest on the search for an effective vaccine. Also included are chapters on the impact of chlamydial infection on specific populations such as the lesbian, gay, bisexual and transgender community, and an update on the outbreak in Europe of the invasive chlamydial infection, lymphogranuloma venereum or LGV. This comprehensive publication is intended for clinicians, public health workers and scientists with interest in sexually transmitted diseases, medical microbiology, infectious diseases and clinical research.

\section{Contents}

Introduction: Black, C.M.

- Epidemiology and Prevention and Control Programs for Chlamydia: Satterwhite, C.L.; Douglas Jr., J.M.

- Chlamydia trachomatis Pathogenicity and Disease: Dean, D.

- Chlamydia trachomatis Genome Structure: Putman, T.E.; Rockey, D.D.

- Chlamydia trachomatis: Molecular Testing

Methods: Gaydos, C.A.

- Treatment of Chlamydia trachomatis Infections: Hammerschlag, M.R.

- The Immunologic Response to Urogenital Infection: Johnson, R.M.; Geisler, w.

-Chlamydia Vaccine Development: Igietseme, J.U.; Black, C.M.

- Maternal and Infant Chlamydia trachomatis Infections: Rours, I.G.I.J.G.; Hammerschlag, M.R. - Chlamydia trachomatis Infection among Sexual Minorities: Singh, D.; Marrazzo, J.M.

- Lymphogranuloma Venereum: A Concise Outline of an Emerging Infection among Men Who Have Sex with Men: de Vries, H.J.C.; Morré, S.

- Author Index

- Subject Index

\section{The easiest way to order: www.karger.com/iinfd}

Karger - Medical and Scientific Publishers

$\mathrm{CH}-4009$ Basel, Switzerland

orders@karger.com, f: +41613061234

www.karger.com 


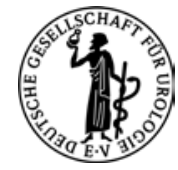

Official Scientific Journal of the Deutsche Gesellschaft für Urologie/ German Society of Urology

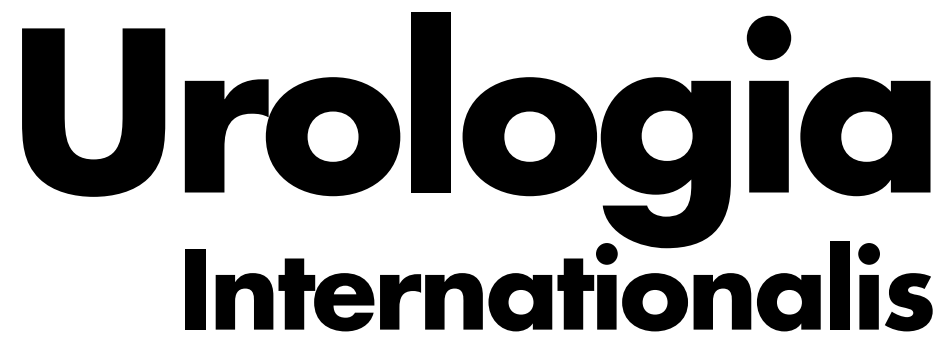

Founded 1955 by G. Peter A. Narath and Heinrich Heusser Successors: G. Mayor (1968-1987); D. Hauri (1988-2005)

\section{Editorial Committee}

S. Egawa, Tokyo

Ph. Jaeger, Uxbridge

V. Mirone, Napoli

R. Mundy, London

J. Nordling, Herlev

P. Rigatti, Milano
H. Rübben, Essen

A. Stenzl, Tübingen

Y. Sun, Shanghai

G. Watson, Eastbourne

W. Weidner, Giessen

B. Wullich, Erlangen

\section{Board of Reviewing Editors}

P. Albers, Düsseldorf

G.L. Andriole, St. Louis

W. Artibani, Verona

M. Babjuk, Prag

G. Baretton, Dresden

P. Bassi, Roma

G. Bogaert, Leuven

N.N.P. Buchholz, London

M. Burger, Würzburg

P. Caione, Roma

E. Costantini, Perugia

P. Dahm, Gainesville

M. Fisch, Hamburg

P. Fornara, Halle

B. Frea, Udine

M. Froehner, Dresden

S. Füssel, Dresden

J.P. Gearhart, Baltimore

T. Hanus, Prague

J. Heesakkers, Nijmegen

W. Horninger, Innsbruck

G. Janetschek, Salzburg

M.M. Karram, Cincinnati

S. Kliesch, Münster

J.N. Krieger, Seattle
M. Lazzeri, Firenze

S. Madersbacher, Wien

V.R. Marshall, Adelaide

A. Martin Morales, Malaga

M. Mas, La Laguna, Tenerife

T.C. Masip, La Laguna, Tenerife

L. Mearini, Perugia

E. Montanari, Milano

G. Morgia, Catania

G. Nicita, Firenze

R.T.D. Oliver, London

C. Protzel, Rostock

P. Radziszewski, Warsaw

P.N. Schlegel, New York

B.J. Schmitz-Dräger, Fürth

S. Siracusano, Trieste

N. Sofikitis, Ioannina

W.L. Strohmaier, Coburg

H.-G. Tiselius, Stockholm

L. Türkeri, Istanbul

F. Verrey, Zürich

F. vom Dorp, Essen

F. Wagenlehner, Giessen

A. Zucchi, Perugia
Printed in Switzerland on acid-free and non-aging paper (ISO 9706) by Reinhardt Druck, Basel
Appears 6-weekly: 2 volumes per year (8 issues) 


\section{Urologia

\section{Submission}

Manuscripts written in English should be submitted using the online submission website at:

\section{www.karger.com/uin}

or as e-mail attachment (the preferred word-processing package is MS-Word) to the Editorial Office:

\section{uin@karger.ch}

S. Karger AG

Editorial Office 'Urologia Internationalis'

P.O. Box

$\mathrm{CH}-4009$ Basel (Switzerland)

Tel. +4161306 1424

Fax +4161306143

The manuscripts should be accompanied by a signed cover letter adressing the points below. A signed copyright transfer statement is required upon acceptance (please see submission website).

\section{Conditions}

All manuscripts are subject to peer review. Manuscripts are received with the explicit understanding that they are no under simultaneous consideration by any other publication. Submission of an article for publication implies the transfer of the copyright from the author to the publisher upon acceptance. Accepted papers become the permanent property of 'Urologia Internationalis' and may not be reproduced by any means, in whole or in part, without the written consent of the publisher. It is the author's responsibility to obtain permission to reproduce illustrations, tables, etc. from other publications.

\section{Cover Letter}

It must include statements on the following points:

1. All authors have made a significant contribution to the findings and methods in the paper.

2. All authors have read and approved the final draft.

3. Financial or commercial interest must be acknowledged.

4. The work has not already been published and has not been submitted simultaneously to any other journal.

5. The corresponding author takes on the above responsibilities with his/her signature.

\section{Plagiarism Policy}

Whether intentional or not, plagiarism is a serious violation. We define plagiarism as a case in which a paper re produces another work with at least $25 \%$ similarity and without citation.

If evidence of plagiarism is found before/after acceptance or after publication of the paper, the author will be offered a chance for rebuttal. If the arguments are not found to be satisfactory, the manuscript will be retracted and the author sanctioned from publishing papers for a period to be determined by the responsible Editor(s).

\section{Arrangement}

Title page: The first page of each paper should indicate the title, the authors' names, the institute where the work was conducted.

In addition, the following should be put on the title page: 1. Short title for use as running head

2. A list of 3-10 key words for indexing purposes is essential

3. Corresponding author: One of the authors has to be indicated as the corresponding author. The full name and complete mailing address, e-mail address, as well as phone and fax numbers of that individual to whom correspondence, proofs, and requests for reprints should be addressed, must be given at the bottom of the title page.

Abstract: Each paper must have a structured abstract (Introduction, Materials and Methods, Results and Conclusions) of up to 20 lines (approximately 150 words). Abstracts of case reports need not be structured.
Footnotes: Avoid footnotes. When essential, they are numbered consecutively and typed at the foot of the appropriate page.

Tables and illustrations: Tables and illustrations (both numbered in Arabic numerals) should be prepared on separate pages. Tables require a heading and figures a legend, also prepared on a separate page. For technical reasons, figures with a screen background should not be submitted. When possible, group several illustrations on one block for reproduction (max size $180 \times 223 \mathrm{~mm}$ ) or provide crop marks. Electronically submitted $b / w$ half-tone and color illustrations must have a final resolution of $300 \mathrm{dpi}$ after scaling, line drawings one of 800-1200 dpi. Figure files must not be embedded in a document file but submitted separately (for detailed instructions, see http://www.karger.com/uin).

Case Reports should include the most important clinical details and not exceed 1,000 words. One table and two figures may be included. References should be limited to ten

Letters to the Editor must include matters of interest to urologists and not exceed 500 words.

Color illustrations

Online edition: Color illustrations are reproduced free of charge. In the print version, the illustrations are reproduced in black and white. Please avoid referring to the colors in the text and figure legends.

Print edition: Up to 6 color illustrations per page can be integrated within the text at CHF 800.- per page.

References: In the text identify references by Arabic numerals [in square brackets]. Material submitted for publication but not yet accepted should be noted as 'unpublished data' and not be included in the reference list. The list of references should include only those publications which are cited in the text. Do not alphabetize; number references in the order in which they are first mentioned in the text. The surnames of the authors followed by initials should be given. There should be no punctuation other than a comma to separate the authors. Preferably, please cite all authors. Abbreviate journal names according to the Index Medicus system. Also see International Committee of Medical Journal Editors: Uniform requirements for manuscripts submitted to biomedical journals (www.icmje.org).

Examples

(a) Papers published in periodicals: Sun J, Koto H, Chung KF. Interaction of ozone and allergen challenges on bronchial responsiveness and inflammation in sensitised guinea pigs. Int Arch Allergy Immunol 1997;112:191-195.

(b) Papers published only with DOI numbers:

Theoharides TC, Boucher W, Spear K: Serum interleukin-6 reflects disease severity and osteoporosis in mastocytosis patients. Int Arch Allergy Immunol DOI: $10.1159 / 000063858$.

(c) Monographs: Matthews DE, Farewell VT: Using and Understanding Medical Statistics, ed 3, revised. Basel, Karger, 1996.

(d) Edited books: Parren PWHI, Burton DR: Antibodies against HIV-1 from phage display libraries: Mapping of an immune response and progress towards antiviral immunotherapy; in Capra JD (ed): Antibody Engineering. Chem Immunol. Basel, Karger, 1997, vol 65, pp 18-56.

Reference Management Software: Use of EndNote is recommended for easy management and formatting of citations and reference lists.

\section{Digital Object Identifier (DOI)}

S. Karger Publishers supports DOIs as unique identifiers for articles. A DOI number will be printed on the title page of each article. DOIs can be useful in the future for identifying and citing articles published online without volume or issue information. More information can be found at www.doi.org

\section{Supplementary Material}

Supplementary material is restricted to additional data that are not necessary for the scientific integrity and conclusions of the paper. Please note that all supplementary files will undergo editorial review and should be submitted together with the original manuscript. The Editors reserve the right to limit the scope and length of the supplementary material. Supplementary material must meet production quality standards for Web publication without the need for any modification or editing. In general, supplementary files should not exceed $10 \mathrm{MB}$ in size. All figures and tables should have titles and legends and all files should be supplied separately and named clearly. Acceptable files and formats are: Word or PDF files, Excel spreadsheets (only if the data cannot be converted properly to a PDF file), and video files (.mov, .avi, .mpeg).

\section{Author's Choice ${ }^{\mathrm{TM}}$}

Karger's Author's Choice ${ }^{\mathrm{TM}}$ service broadens the reach of your article and gives all users worldwide free and full access for reading, downloading and printing at www. karger.com. The option is available for a one-time fee of CHF 3000.-, which is a permissible cost in grant allocation. More information can be found at www.karger.com/ authors_choice.

\section{NIH-Funded Research}

The U.S. National Institutes of Health (NIH) mandates under the NIH Public Access Policy that final, peer-reviewed manuscripts appear in its digital database within 12 months of the official publication date. As a service to authors, Karger submits the final version of your article on your behalf to PubMed Central. For those selecting our premium Author's Choice ${ }^{\mathrm{TM}}$ service, we will send your article immediately upon publishing, accelerating the accessibility of your work without the usual embargo. More details on NIH's Public Access Policy is available at http://publicaccess.nih.gov/FAQ.htm\#al

\section{Self-Archiving}

Karger permits authors to archive their pre-prints (i.e. prerefereeing) or post-prints (i.e. final draft post-refereeing) on their personal or institution's servers, provided the following conditions are met: Articles may not be used for commercial purposes, must be linked to the publisher's version, and must acknowledge the publisher's copyright. Authors selecting Karger's Author's Choice ${ }^{\mathrm{TM}}$ feature, how ever, are also permitted to archive the final, published version of their article, which includes copyediting and design improvements as well as citation links.

\section{Page Charges}

There are no page charges for original papers of 3 or fewer printed pages $(3,000$ words including tables, illustrations and references) or for case reports with 2 or fewer printed pages. Each extra complete or partial page is charged to the author at CHF 325.-. The allotted size of a paper is equal to approx. 8 manuscript pages double-spaced (including tables, illustrations and references). The inability to pay charges for extra pages will not prejudice publication of the paper. This will be decided by the Editors.

Proofs

Pdf proofs will be sent to the corresponding author and should be returned with the least possible delay.

\section{E-pub First}

All articles are published electronically ahead of print with a DOI number and are supplemented later with the definite reference of the printed version. The articles become available immediately after the authors' approval to publication, with the added advantage of being citable much earlier than in print. Authors can influence the time of appearance by promptly returning the proofs.

\section{Reprints}

Order form and price list is sent with the pdf proofs. Orders submitted after the issue is printed are subject to considerably higher prices.

\section{KARGER}

E-Mail karger@karger.com www.karger.com
(C) 2013 S. Karger AG, Basel 


\section{Urologia \\ Internationalis}

ISSN Print Edition: 0042-1138

ISSN Online Edition: 1423-0399

Journal Homepage: www.karger.com/uin

Publication Data: 'Urologia Internationalis' is published 8 times a year. Volumes 90-91, each with 4 issues, appear in 2013.

Copyright: (c) 2013 S. Karger AG, Basel (Switzerland). All rights reserved. No part of this publication may be translated into other languages, reproduced or utilized in any form or by any means, electronic or mechanical including photocopying, recording, microcopying, or by any information storage and retrieval system, without permission in writing from the publisher or, in the case of photocopying, direct payment of a specified fee to the Copyright Clearance Center.

Disclaimer: The statements, opinions and data contained in this publication are solely those of the individual authors and contributors and not of the publisher and the editor(s). The appearance of advertisements in the journal is not a warranty, endorsement, or approval of the products or services advertised or of their effectiveness, quality or safety. The publisher and the editor(s) disclaim responsibility for any injury to persons or property resulting from any ideas, methods, instructions or products referred to in the content or advertisements.
Subscription Rates: Subscriptions run for a full calendar year. Prices are given per year. Personal subscription:

Print or Online

CHF 2250.-

EUR 1814.-

USD 2228.00

Print+Online combined CHF 2346.-

EUR 1892.-

USD 2324.00

postage and handling (added to print and print+online)

CHF 57.60 Europe, CHF 83.20 Overseas

EUR 44.80

USD 76.80

Institutional subscription

Print or Online

Print+Online combined

CHF 4498.

EUR 3628.-

CHF 4948.-

postage and handling (added to print and print+online)

CHF 72.- Europe, CHF 104.- Overseas

EUR 56.-

USD 96.00

Airmail surcharge: CHF 70.- / USD 66.00

Discount subscription prices:

National and international urological societies.
Back Volumes and Single Issues: Information on availability and prices of single print issues and print or electronic back volumes can be obtained from Customer Service atservice@karger.com.

Bibliographic Indices: This journal is regularly listed in bibliographic services, including Current Contents ${ }^{\circledR}$ and PubMed/MEDLINE.

Photocopying: This journal has been registered with the Copyright Clearance Center (CCC), as indicated by the code appearing on the first page of each article. For readers in the US, this code signals consent for copying of articles for personal or internal use, or for the personal or internal use of specific clients, provided that the stated fee is paid per copy directly to

Copyright Clearance Center Inc.

222 Rosewood Drive

Danvers, MA 01923 (USA)

A copy of the first page of the article must accompany payment. Consent does not extend to copying for general distribution, for promotion, for creating new works, or for resale. In these cases, specific written permission must be obtained from the copyright owner,

S. Karger AG, P.O. Box

CH-4009 Basel (Switzerland).

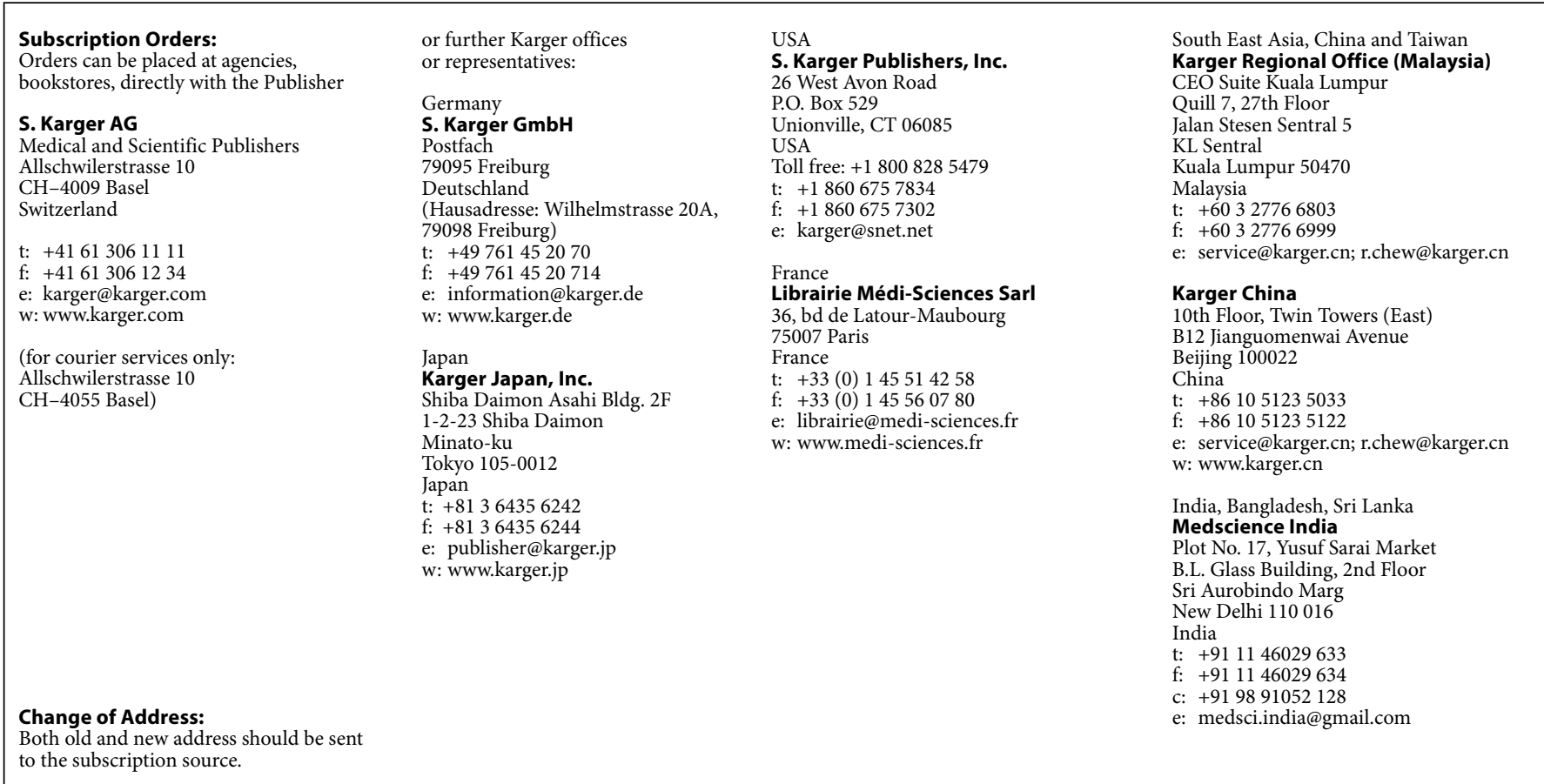

\section{KARGER}

E-Mail karger@karger.com www.karger.com

\section{(C) 2013 S. Karger AG, Basel}

The Journal Home Page is available at:

www.karger.com/uin 


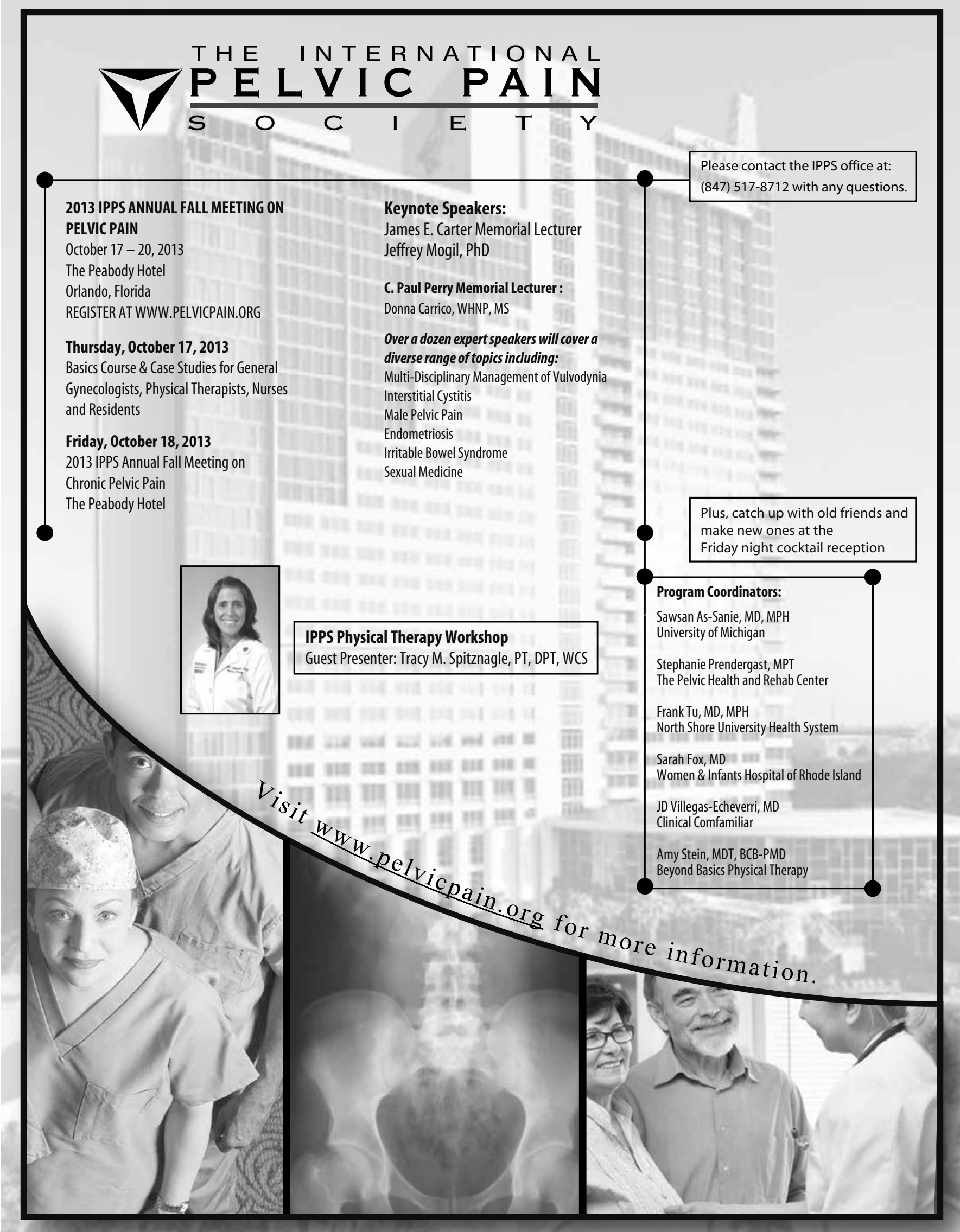




\section{Contents}

See the journal website for contents

KARGER Basel $\bullet$ Freiburg $\cdot$ Paris $\bullet$ London $\bullet$ New York $\cdot$ New Delhi $•$ Bangkok Beijing $\cdot$ Tokyo $\cdot$ Kuala Lumpur $\cdot$ Singapore $\bullet$ Sydney 


\section{SIJ UK Section Meeting "Stones, Shocks \& Seopes" November 22, 2013 London, UK}

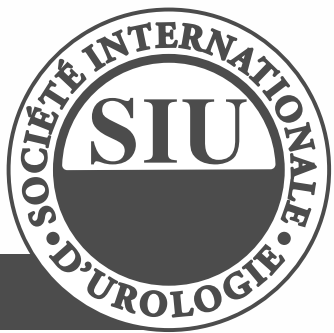

\section{Chairman: Noor Buchholz}

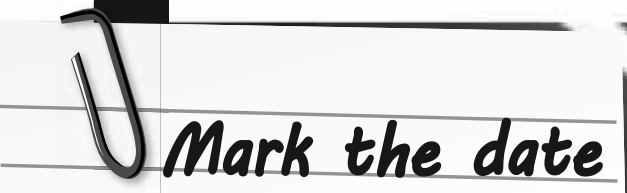

A meeting for residents and urologists,
trainees and trainers

oreoper

\section{Www.2013siu-ukmeeting..e0m}

- State-of-tho-art lobturas

- Unedited video oparations

- Posters and fres presentations

- Best postor and presentation awards

- Iands on workshops on PQil and flexible Uifs

- "Vightmare" eases of eomplieations

Submit your abstract NOW for poster and free paper presentation 


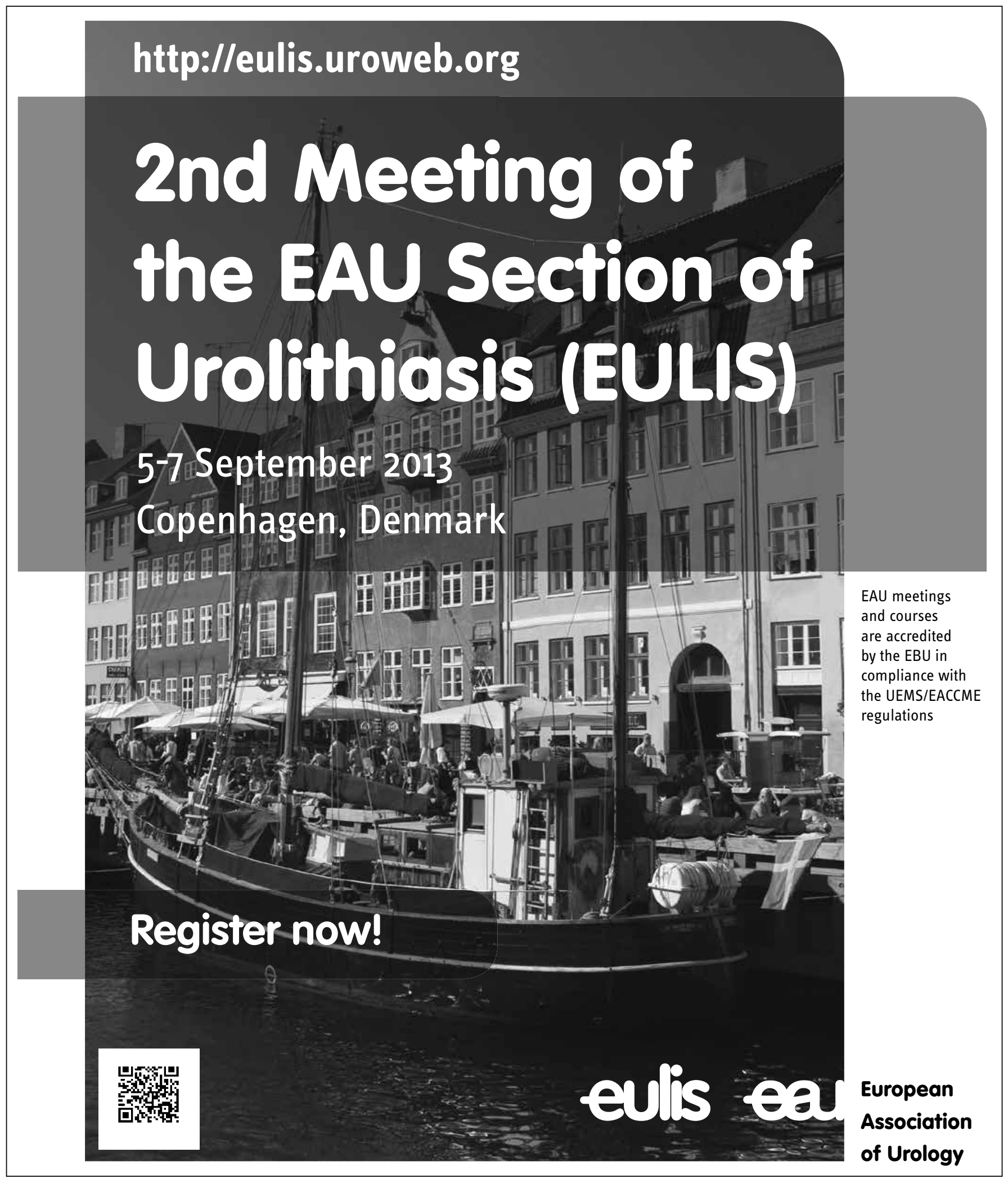




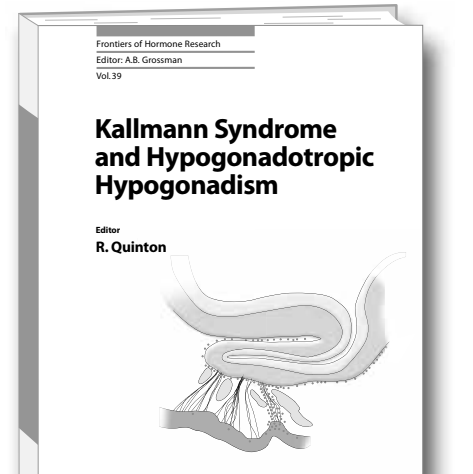

KARGER

\title{
Kallmann Syndrome and Hypogonadotropic Hypogonadism
}

\author{
Editor \\ Richard Quinton
}

Over the past decade, the understanding of the processes involved in the regulation of gonadotropin-releasing hormone and its dysfunction has greatly increased. As new regulatory peptides have been identified, the underlying causes of central hypogonadism have multiplied, and the area has become increasingly complex. The reversibility of even genetically determined hypogonadotropic hypogonadism has become more firmly established, and clinical studies have greatly expanded our understanding of basic physiological pathways. Structuring this mass of new knowledge in thirteen comprehensive chapters, a group of renowned experts, representing the principal international research groups, take stock of the most recent progress.

This up-to-date overview helps scientists and clinicians to plan future research and treat patients with delayed puberty, hypogonadotropic hypogonadism and other forms of central reproductive disorders.

\section{Contents}

Foreword: Grossman, A.B.

Preface: Quinton, $\boldsymbol{R}$.

Molecular Characterization and Phenotypic Expression of Mutations in Genes for Gonadotropins and Their Receptors in Humans: Salvi, R.; Pralong, F.P.

Role of Kisspeptin/GPR54 System in Human Reproductive Axis: Silveira, L.F.G.; Teles, M.G.; Trarbach, E.B.; Latronico, A.C.

Biology of Kisspeptins: Hameed, S.; Dhillo, W.S.

Role of Fibroblast Growth Factor Signaling in Gonadotropin-Releasing Hormone Neuronal System Development: Chung, W.C.J.; Tsai, P.-S.

FGFR1 Mutations in Kallmann Syndrome: Villanueva, C.; de Roux, $\boldsymbol{N}$.

Biology of KAL1 and Its Orthologs: Implications for X-Linked Kallmann Syndrome and the Search for Novel Candidate Genes: MacColl, G.S.; Quinton, R.; Bülow, H.E.

Biological Actions and Interactions of Anosmin-1:Choy, C.; Kim, S.-H.

Genotype and Phenotype of Patients with Gonadotropin-Releasing Hormone Receptor Mutations: Kim, H.-G.; Pedersen-White, J.; Bhagavath, B.; Layman, L.C.
Hypogonadotropic Hypogonadism and GNRH1 Mutations in Mice and Humans: Bouligand, J.; Ghervan, C.; Guiochon-Mantel, A.; Young, J.

Kallmann Syndrome Caused by Mutations in the PROK2 and PROKR2 Genes: Pathophysiology and GenotypePhenotype Correlations: Sarfati, J.; Dodé, C.; Young, J.

Neurokinin B and Its Receptor in Hypogonadotropic Hypogonadism: Semple, R.K.; Topaloglu, A.K.

Complex Genetics in Idiopathic Hypogonadotropic Hypogonadism: Pitteloud, N.; Durrani, S.; Raivio, T.; Sykiotis, G.P.

Rarer Syndromes Characterized by Hypogonadotropic Hypogonadism: Aminzadeh, $\boldsymbol{M}$.; Kim, H.-G.; Layman, L.C.; Cheetham, T.D.

Concluding Remarks: Ravikumar, B.; Crowley, W.F., Jr.

Author Index

Subject Index

www.karger.com/fhore

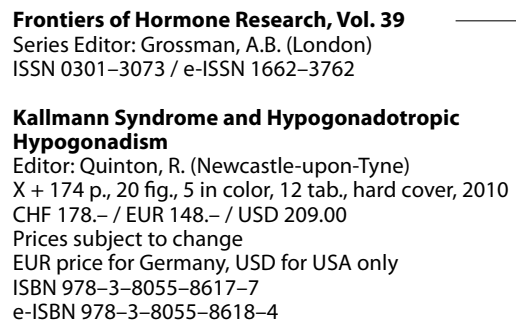

\section{$\rightarrow$ Please send: ___ copy/ies}

$\boldsymbol{\varepsilon}$

Postage and handling free with prepayment

Payment:

Please charge to my credit card

- $\square$ American Express $\square$ Diners $\square$ Eurocard

$\square$ American Express $\square$ Diners

- Card No.:

$\boldsymbol{1}$

Exp. date:

CVV/CVC

( 3 digits in the signature field on the back of Visa and MasterCard)

$\square$ Check enclosed $\square$ Please bill me

Orders may be placed with any bookshop, subscription agency, directly with the publisher or through a Karger distributor.
Fax: +41 613061234

S. Karger AG, P.O. Box, CH-4009 Basel (Switzerland) E-Mail orders@karger.ch,www.karger.com

Name/Address: 


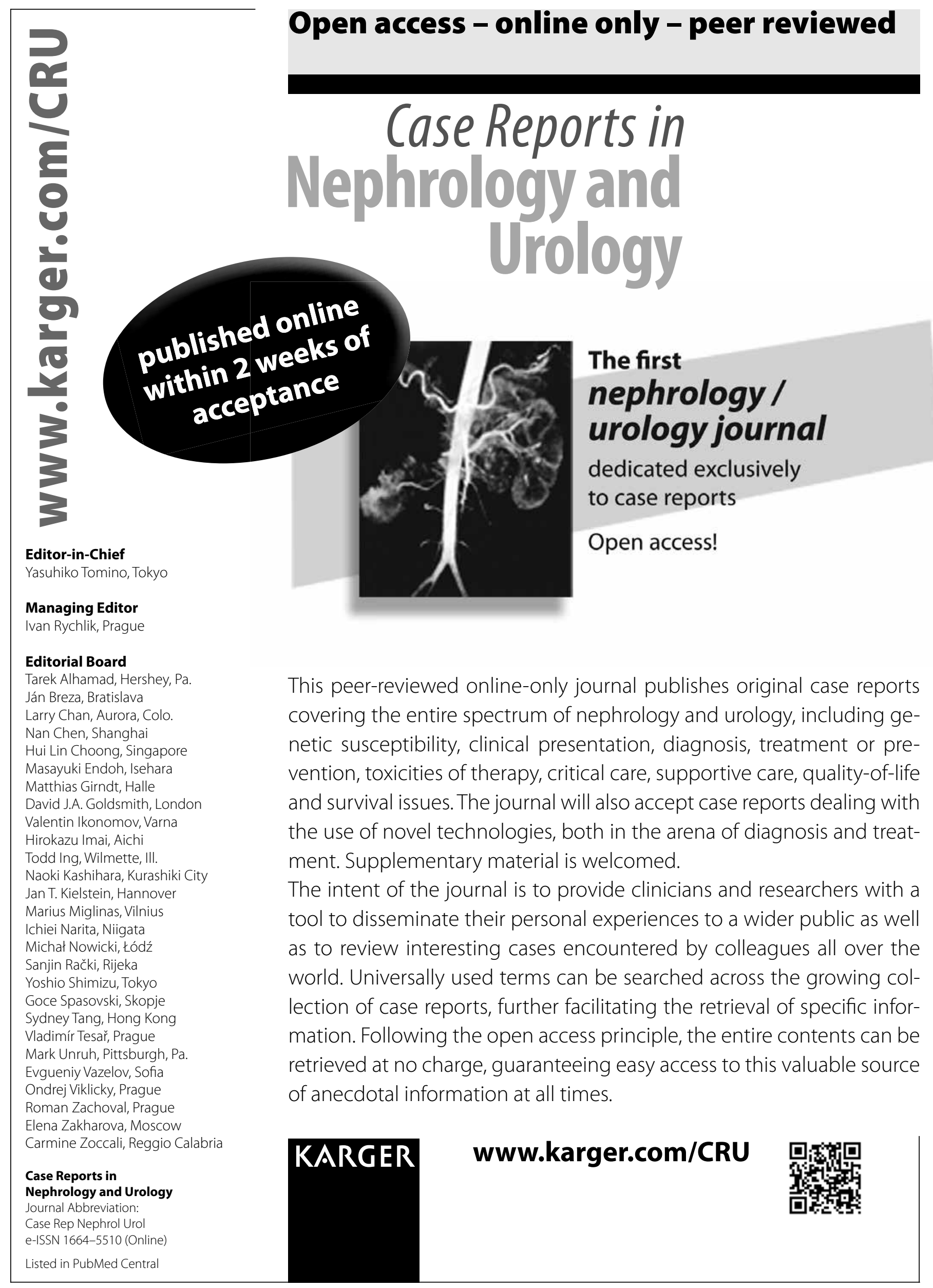




\section{Urologia Internationalis}

(Continued from back cover)

206 A Functional Insertion/Deletion Polymorphism (-94 ins/del ATTG) in the Promoter Region of the NFKB 1 Gene Is Related to the Risk of Renal Cell Carcinoma

Cai, H. (Nanjing); Sun, L. (Qingdao); Cui, L. (Changzhou); Cao, Q.; Qin, C. (Nanjing); Zhang, G.; Mao, X. (Qingdao); Wang, M.; Zhang, Z.; Shao, P.; Yin, C. (Nanjing)

213 Lack of Association between COMT Val158Met Polymorphism and Prostate Cancer Susceptibility Zhang, H.; Zhang, Z.; Wu, J.; Xu, Y.; Cheng, R.; Li, L. (Tianjin)

220 Association between IL-1RN VNTR, IL-1 $\beta$-511 and IL-6 (-174, -572, -597) Gene Polymorphisms and Urolithiasis

Çoker Gurkan, A.; Arisan, S.; Arisan, E.D.; Sönmez, N.C.; Palavan Ünsal, N. (Istanbul)

227 The Role of Fascin in Migration and Invasion of Urothelial Carcinoma of the Bladder

Bi, J.; Zhu, Y. (Shenyang); Chen, X. (Chaoyang); Yu, M.; Zhang, Y.; Li, B.; Sun, J.; Shen, H.; Kong, C. (Shenyang)
Case Reports

236 Mini-Percutaneous Nephrolithotomy with Ureteral Access Sheath in a Transplanted Kidney: Case Report and Literature Review

Kadlec, A.O.; Ross, M.J.; Milner, J.E. (Maywood, Ill.)

239 Micropercutaneous Nephrolithotomy (Microperc) in a Two-Year-Old with the 'All-Seeing Needle'

Kaynar, M.; Sümer, A.; Şalvarc1, A.; Tekinarslan, E.; Cenker, A.; Istanbulluoğlu, M.O. (Konya)

242 Right-Sided Hydronephrosis Secondary to Swallowing a Headscarf Pin

Alkan, E.; Ozkanli, O.; Balbay, D. (Istanbul)

245 A Giant Adrenal Pseudocyst Mimicking an Adrenal Cancer: Case Report and Review of the Literature Passoni, S.; Regusci, L.; Peloni, G.; Brenna, M.; Fasolini, F. (Mendrisio) 


\section{Urologia Internationalis}

Review

125 Adrenal Oncocytic Neoplasm: A Systematic Review Mearini, L.; Del Sordo, R.; Costantini, E.; Nunzi, E.; Porena, M. (Perugia)

Surgical Technique

134 New Surgical Technique for the Treatment of Buried Penis: Results and Comparison with a Traditional Technique in $\mathbf{7 5}$ Patients

Spinoit, A.-F.; De Prycker, S.; Groen, L.-A.; van Laecke, E.; Hoebeke, P. (Ghent)

Original Papers

140 Urinary Retention: Benefit of Gradual Bladder Decompression - Myth or Truth? A Randomized Controlled Trial

Boettcher, S.; Brandt, A.S.; Roth, S.; Mathers, M.J.; Lazica, D.A. (Wuppertal)

145 Safe Introduction of Robot-Assisted Radical Prostatectomy after a Training Program in a High-Volume Robotic Centre

Lumen, N.; Van Praet, C.; De Troyer, B.; Fonteyne, V.; Oosterlinck, W.; Decaestecker, K. (Ghent); Mottrie, A (Ghent/Aalst)

153 Predictive Factors for Bladder Recurrence after Radical Nephroureterectomy for Upper Urinary Tract Urothelial Carcinoma

Cho, D.S. (Seongnam); Kim, S.I.; Ahn, H.S.; Kim, S.J. (Suwon)

160 Should Bone Scan be Performed in Chinese Prostate Cancer Patients at the Time of Diagnosis?

Wang, Y.; Guo, J.; Xu, L.; Zhao, N.; Xu, Z.; Wang, H.; Zhu, Y.; Jiang, S.; Yang, N.; Yang, Y.; Wang, G. (Shanghai)
165 Severity of Urinary Incontinence of Nursing Home Residents Correlates with Malnutrition, Dementia and Loss of Mobility

Rose, A.; Thimme, A.; Halfar, C.; Nehen, H.G.; Rübben, H. (Essen)

170 Transitional Cell Carcinoma of the Ureteric Stump: A Systematic Review of the Literature

Bourdoumis, A.; Syed, I. (London); Soosay, G. (Romford); Manzoor, A.; Barua, J. (London)

175 Validation of RiskCheck Bladder Cancer ${ }^{\circ}$, Version 5.0 for Risk-Adapted Screening of Bladder Cancer

Martini, T.; Mayr, R.; Lodde, M. (Bolzano); Seitz, C. (Vienna); Trenti, E.; Comploj, E.; Palermo, S.; Pycha, A.; Mian, C. (Bolzano); Zywica, M. (Bressanone); Weidner, W.; Lüdecke, G. (Giessen)

182 Time between First and Second Transurethral Resection of Bladder Tumors in Patients with High-Grade T1 Tumors: Is It a Risk Factor for Residual Tumor Detection? Süer, E.; Özcan, C.; Baltacı, S.; Gülpınar, Ö.; Burgu, B.; Haliloğlu, A.; Bedük, Y. (Ankara)

187 Cardiovascular Risk Assessment Using High-Sensitivity C-Reactive Protein in Patients with Erectile Dysfunction Ferrandis-Cortes, C.; Martínez-Jabaloyas, J.M.; Díez-Calzadilla, N.A.; Hernández-Medina, J.A.; Chuan-Nuez, P. (Valencia)

192 Laparoscopic Varicocelectomy in Infertile Men: Does Age Matter?

El-Shazly, M. (Ardiya); Eissa, B. (Cairo)

197 Role of Tramadol in Premature Ejaculation: A Systematic Review and Meta-Analysis

Yang, L.; Qian, S.; Liu, H.; Liu, L.; Pu, C.; Han, P.; Wei, Q. (Chengdu)

(Continued on inside back cover) 